\title{
Maximizing the Output Power of Wind-Driven Grid-Connected Cage Induction Generator through Pole Control
}

\author{
M. A. Abdel-Halim and Abdulkarim Alghunaim \\ College of Engineering, Qassim University, Municipality of Qassim Region, Qassim, Saudi Arabia \\ masamie@qec.edu.sa
}

\begin{abstract}
In this research, a cage induction generator has been linked to the grid and driven with a wind-turbine to generate electrical power. The cage generator has been used in place of the costly slip-ring generator. The performance characteristics of the cage induction generator have been ameliorated through changing its number of poles to comply with the level of the wind speed to maximize the mechanical power extracted from the wind. Pole changing has been achieved employing pole-amplitude modulation technique resulting in three sets of pole numbers. The results proved the feasibility and effectiveness of the suggested method, as the proposed technique led to driving the generator, and consequently the wind-turbine at speeds close or equal to those satisfying the optimum tip-speed ratio which corresponds to the point of maximum mechanical power.

Keywords: Wind energy, Grid-connected Induction Generator, Pole-amplitude Modulation, Cage Induction Generator.
\end{abstract}

List of Symbols:

$\mathrm{C}_{\mathrm{p}}$ : Wind power coefficient

$\mathrm{C}_{\mathrm{Q}}$ : Wind torque coefficient

$\mathrm{I}_{\mathrm{r}}:$ Rotor current

$\mathrm{I}_{\mathrm{s}}:$ Stator current

$\mathrm{n}_{\mathrm{m}}$ : Generator speed

$\mathrm{n}_{\mathrm{s}}$ : Synchronous speed

$\mathrm{V}_{\mathrm{s}}$ : Stator voltage

$\mathrm{V}_{\mathrm{w}}$ : Wind speed

$\mathrm{P}_{\mathrm{T}}$ : Turbine output power

$\mathrm{R}_{\mathrm{r}}$ : Rotor resistance

$\mathrm{R}_{\mathrm{s}}$ : Stator resistance

$\mathrm{R}_{\mathrm{c}}$ : Core resistance

$R_{T}$ : Thevinin's equivalence resistance

$\mathrm{R}_{\mathrm{b}}$ : Radius of the turbine blade

$\mathrm{X}_{\mathrm{r}}$ : Rotor leakage reactance

$\mathrm{X}_{\mathrm{s}}$ : Stator leakage reactance

$X_{\mathrm{m}}$ : Magnetizing reactance

$\mathrm{Z}_{\mathrm{ms}}$ :The equivalent series impedance

$X_{T}$ : Thevinin's equivalence reactance s: Per-unit slip

$\beta$ : Blade pitch angle

$\lambda$ : Tip-speed ratio

$\omega_{\mathrm{T}}$ : Angular speed of the wind turbine

$\tau$ : Generator induced torque

$\tau_{\mathrm{T}}$ : Turbine output torque

\section{Introduction}

The utilization of wind energy is very important and finds nowadays great interest. This interest has become vital as the world is going to face great shortage in the conventional energy resources. Therefore, generation of electrical energy from the renewable wind energy has become an essential goal of energy researches. The windturbines as prime movers have variable and unexpected velocities. If synchronous generators are used, the frequency of the 
generated voltage will be variable as it is tied to the prime-mover speed. Therefore, the need to other types of generators or unconventional solutions arises. Using of induction generators solve the problem of these variable speed turbines ${ }^{[1-3]}$.

Most of the research works carried out in this field aimed at maximizing the power efficiency of the wind-driven inductiongenerator by controlling the system such that the turbine always extracts the possible maximum wind-power at all wind speeds ${ }^{[4-10]}$.

Shaltout, et al., ${ }^{[4]}$ proposed a simple control strategy of a double fed induction generator (DFIG) to track the maximum power available at different wind speeds using a rectifier-inverter set in the rotor. Abdel-halim et al. ${ }^{[5]}$ proposed a technique for the rotor injected voltage of a DFIG such that the wind turbine tracks the maximum wind energy, and at the same time the stator current is kept at unity power factor. Boumassata et al. ${ }^{[6]}$ proposed a system constituting of a DFIG using a controlled cycloconverter in the rotor aiming at improving the maximum power point tracking. Abdel-halim, et al. ${ }^{[7,}$ 8] suggested a method of controlling the induction generator such that the driving windturbine follows the point of maximum wind power. This is employed through dual control using a cycloconverter in the stator side and three added resistances in the rotor side. Other authors suggested controlling the IG from the stator side using rectifier-inverter set ${ }^{[9]}$ with the aim of tracing the maximum wind power points, or using a cycloconverter ${ }^{[10]}$ to drive the generator as near as possible to these maximum points.

In general, control of the induction generators is achieved via the use of solid-state converters in the stator and/or the rotor sides. When solid-state converters are used in the rotor side, they will be of reduced rating (about $25 \%$ of the generator rating) ${ }^{[11]}$. But in this case, the induction generator should have a slip ring rotor, which is expensive compared to the cage one. To control the cheaper cage induction generator utilizing rectifier-inverter set, the converters should be used in the stator, which is the only available side. In this case, if a rectifier-inverter set is used, its rating should be the same as that of the generator, which is again costly. To avoid such costly converters, another control techniques have to be used for the cage induction generators such as changing the number of poles.

Linni Jian, et al. ${ }^{[12]}$ proposed a novel double-winding flux modulated permanent magnet machine (FMPM) for stand-alone wind power generation. Based on the fluxmodulating effect, a concentrated winding set and a distributed winding set could be artfully equipped on one stator component. The authors showed that the proposed FMPM can offer higher torque capability and stronger flux adjustability than the existing single-winding FMPMs generators.

It is noted that mostly the cage induction generator has been used in constant speed systems $[3,11]$. The present paper aims at increasing the output electrical power of the induction generators at the different wind speeds through the control of the stator number of poles. Pole control will be achieved via changing the machine number of poles using pole amplitude modulation technique for the stator winding ${ }^{[13]}$. The study will end with suggesting control strategies to maximize the output electrical power from the generator.

The research will be performed through developing a circuit model for the controlled grid-connected cage induction generator considering pole-changing. Then, a mathematical model will be developed for the complete system. Based on this model, the performance characteristics of the system will 
be computed, and a comprehensive analysis for the performance characteristics of the controlled generator will be carried out.

\section{Studied System}

The system under study comprises a wind-driven grid-connected cage induction generator controlled by pole amplitude modulation technique. The generator is directly linked to the grid (Fig. 1).

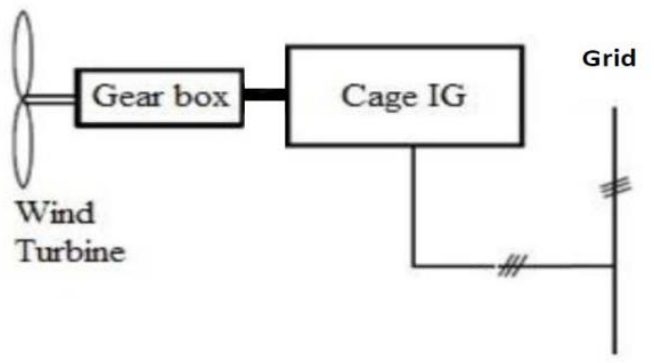

Fig. 1. The wind-driven grid-connected induction generator system.

\section{Control Method}

To increase the output power of the system, it is necessary to increase the extracted power of the wind. This is achieved by driving the generator at speed such that the turbine tipspeed ratio is equal or very near to the optimum value $\left[\begin{array}{lll}14 & \& & 15\end{array}\right]$. Pole amplitude modulation technique ${ }^{[13]}$ will be used to adjust the generator speed at 3 levels. This technique is done to extract the maximum wind power through adjusting the turbine tip-speed ratio to be close to its optimum value.

\subsection{Pole-Amplitude Modulation (PAM)}

In this technique the windings are grouped in two sections, and the current direction in one section of each phase is reversed with respect to the other. This method utilizes the norm of amplitude-modulation to the space-distribution of the magnetic motive force produced by the windings. The windings design procedure is based on trigonometrical equations ${ }^{[13]}$.
In two-speed PAM windings the connections of the three phase windings were 2-parallel-star/ series-delta ${ }^{[16,17]}$. For threespeed PAM windings, three speeds are made possible by using 4-parallel-star/ 2-parallelstar/ series delta switching ${ }^{[13]}$, using the circuit shown in Fig. 2. Table 1 explains how the terminals are dealt with to get the 3 different pole numbers that gives the 3 different speeds.

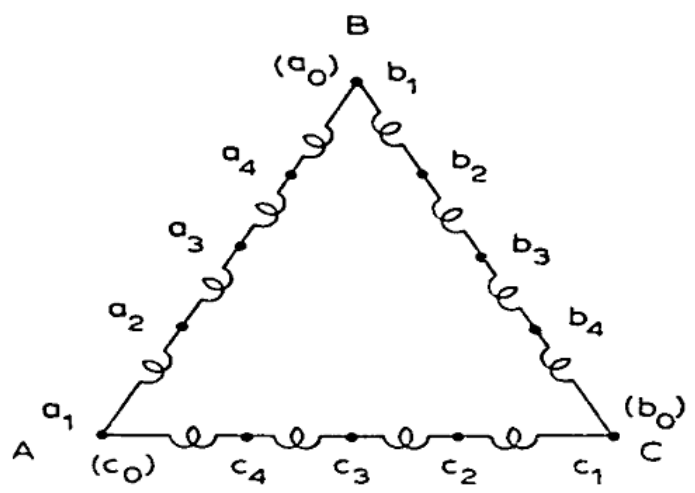

Fig. 2. Circuit diagram for 3 speed pole-amplitude modulation.

Table 1. Different connections and supplying patterns for the 3-speeds PAM.

\begin{tabular}{|l|l|l|}
\hline $\begin{array}{l}\text { Speed I (4- } \\
\text { Parallel-star) }\end{array}$ & $\begin{array}{l}\text { Speed II (2- } \\
\text { Parellel-star) }\end{array}$ & $\begin{array}{l}\text { Speed III } \\
\text { (Series-delta) }\end{array}$ \\
\hline Join $\mathrm{a}_{1} \mathrm{~b}_{1} \mathrm{c}_{1}$ Join & Join $\mathrm{a}_{1} \mathrm{~b}_{1} \mathrm{c}_{1}$ & Isolate $\mathrm{a}_{2} \mathrm{a}_{3} \mathrm{a}_{4}$ \\
$\mathrm{a}_{3} \mathrm{~b}_{3} \mathrm{c}_{3}$ & Isolate $\mathrm{a}_{2} \mathrm{a}_{4} \mathrm{~b}_{2} \mathrm{~b}_{4}$ & $\mathrm{~b}_{2} \mathrm{~b}_{3} \mathrm{~b}_{4} \mathrm{c}_{2} \mathrm{c}_{3} \mathrm{c}_{4}$ \\
$\mathrm{~J}_{\mathrm{Jin}} \mathrm{a}_{2} \mathrm{a}_{4} ; \mathrm{b}_{2} \mathrm{~b}_{4} ;$ & $\mathrm{c}_{2} \mathrm{c}_{4}$ & Supply $\mathrm{a}_{1} \mathrm{~b}_{1} \mathrm{c}_{1}$ \\
$\mathrm{c}_{2} \mathrm{c}_{4}$ & Supply $\mathrm{a}_{3} \mathrm{~b}_{3} \mathrm{c}_{3}$ & \\
Supply $\mathrm{a}_{2} \mathrm{a}_{4} ; \mathrm{b}_{2}$ & & \\
$\mathrm{~b}_{4} ; \mathrm{c}_{2} \mathrm{c}_{4}$ & & \\
\hline
\end{tabular}

\section{System Modelling}

\subsection{Wind Turbine Mathematical Model}

Wind turbines are equipment specially designed to convert amount of the energy of the wind into useful mechanical energy. Depending on the direction of the turbine axis, wind turbines are classified into vertical-axis and horizontal-axis ones ${ }^{[18]}$. Nowadays, almost all commercial wind turbines used in conjunction with generators to deliver electrical power to grids have horizontal-axis two-bladed or three-bladed rotors. 
The turbine output torque and power are usually expressed in terms of non-dimensional torque $\left(\mathrm{C}_{\mathrm{Q}}\right)$ and power $\left(\mathrm{C}_{\mathrm{P}}\right)$ coefficients as follows ${ }^{[14,15]}$.

$\tau_{T}=\frac{1}{2} \rho \pi R_{b}^{3} C_{Q}(\lambda \cdot \beta) V_{W}^{2}$

$P_{T}=\frac{1}{2} \rho \pi R_{b}^{2} C_{P}(\lambda \cdot \beta) V_{W}^{3}$

$C_{Q}=C_{P} / \lambda$

Note that the two coefficients are written in terms of the pitch angle and the so-called tip-speed-ratio; $\lambda$, defined as

$\lambda=\left(\omega_{T} R_{b}\right) / V_{w}$

Where $R_{b}$ is the radius of the turbine blade in meter, $\omega_{T}$ is the turbine angular velocity in $\mathrm{rad} / \mathrm{s}$, and $V_{w}$ is the wind speed in $\mathrm{m} / \mathrm{s}$. Fig. 3 shows typical variations of $C_{\mathrm{Q}}$ and $C_{\mathrm{p}}$ for a fixed-pitch wind turbine ${ }^{[15]}$.

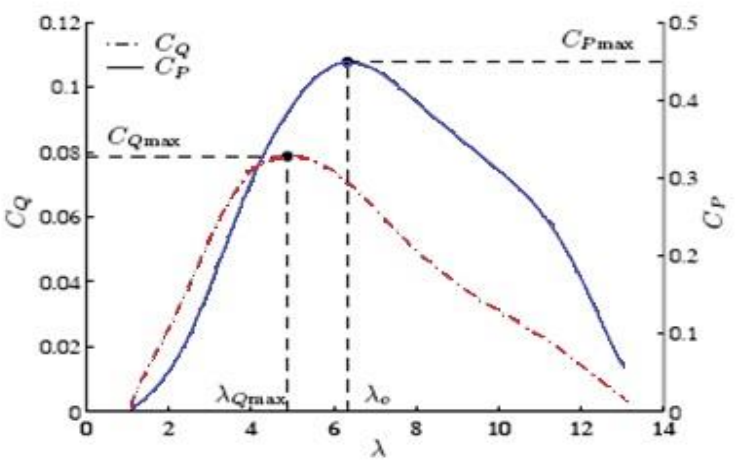

Fig. 3. Typical variations of $C Q$ and $C P$ for a fixed-pitch wind turbine.

\subsection{Induction Generator Circuit Model}

Figure 4 shows a frequency-domain perphase circuit model of the 3-phase induction generator ${ }^{[3]}$. The equivalent circuit parameters depend on the number of poles of the generator $^{[12]}$.

The parameters of the equivalent circuit depends on the number of stator poles which is set through variation of the stator circuit topology ${ }^{[13]}$.

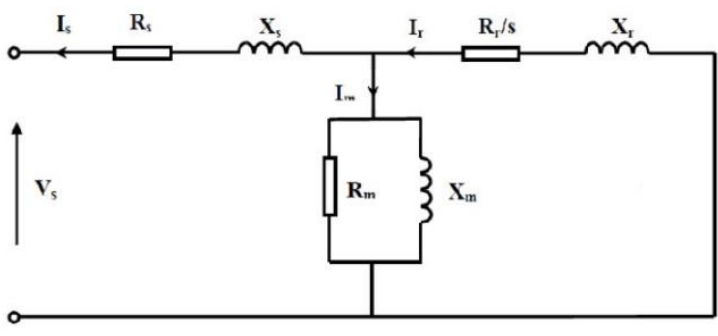

Fig. 4. Per-phase equivalent circuit of the induction generator.

\subsection{Induction Generator Mathematical Model}

The induced torque of the induction generator is related to applied voltage, slip and the equivalent circuit parameters as follows ${ }^{[3]}$ :

$\tau=\frac{3 \mathrm{~V}_{\mathrm{T}}^{2} \mathrm{R}_{\mathrm{r}} / \mathrm{s}}{\omega_{\mathrm{s}}\left[\left(\mathrm{R}_{\mathrm{T}}+\mathrm{R}_{\mathrm{r}} / \mathrm{s}\right)^{2}+\left(\mathrm{X}_{\mathrm{T}}+\mathrm{X}_{\mathrm{r}}\right)^{2}\right]}$

where $V_{T}, R_{T}$ and $X_{T}$ are Thevenin's equivalent circuit parameters of the stator. These are given by

$V_{T}=\frac{\mathrm{V}_{\mathrm{s}} \mathrm{Z}_{\mathrm{ms}}}{\sqrt{\left(\mathrm{R}_{\mathrm{s}}+\mathrm{R}_{\mathrm{cs}}\right)^{2}+\left(\mathrm{X}_{\mathrm{s}}+\mathrm{X}_{\mathrm{ms}}\right)^{2}}}$

$R_{T}+\mathrm{j} X_{T}=\left(\mathrm{R}_{\mathrm{s}}+\mathrm{jX}_{\mathrm{s}}\right) / / \mathrm{jX}_{\mathrm{m}} / / \mathrm{R}_{\mathrm{c}}$ (4.7)

where $R_{\mathrm{cs}}$ and $\mathrm{X}_{\mathrm{ms}}$ are the components of $\mathrm{Z}_{\mathrm{ms}}$ (The equivalent series impedance of the parallel components; $\mathrm{R}_{\mathrm{c}}$ and $\mathrm{X}_{\mathrm{m}}$ ).

\section{Computation Algorithm}

A computer program has been developed to compute the performance of the induction generator using pole-modulation-amplitude when driven by wind turbine at the different wind speeds. The computations have been based on the mathematical models given in Section 4.2. The algorithm followed during computing the performance for the different number of poles is as follows:

i- At a certain wind speed and number of poles, the tip-speed ratio $(\lambda)$ is initially calculated assuming that the speed of generator is equal to its synchronous speed using Eqn. 4.4 Then, the torque coefficient $\left(\mathrm{C}_{\mathrm{Q}}\right)$ is determined using the turbine 
characteristic (Fig. 3), and the torque of the wind turbine is calculated using Eqn. 4.1.

ii- The slip is calculated using Eqn. 4.5, and a new speed of the generator is calculated. Then, $\lambda, \mathrm{C}_{\mathrm{Q}}$ and the wind turbine torque are recalculated. The iterative technique continues until no variation in the slip occurs.

iii- At the calculated value of the slip, the equivalent circuit (Fig. 4) is used to calculate the generator currents, power factor, output power, losses etc.

iv- The calculation is repeated for different wind speeds over the wind speed rang and for the three sets of poles.

\section{Results and Discussion}

The developed computer program has been applied on a generator of the data given in Appendix 1. The performance characteristics at different number of poles, namely; 4, 6 and 8 have been calculated. The captured mechanical power from the wind is affected by the number of poles (Fig. 5). As the wind speed decreases, the number of poles should be increased to extract more mechanical power from the wind. For the studied generator, for speeds higher than about $9.6 \mathrm{~m} / \mathrm{s}$ 4-poles should be used, while when the generator number of poles is changed to 6poles, more mechanical power is extracted when the wind speed ranges between $9.6 \mathrm{~m} / \mathrm{s}$ and $6.8 \mathrm{~m} / \mathrm{s}$. To extract the highest mechanical power at wind speeds lower than $6.8 \mathrm{~m} / \mathrm{s}$, the number of poles should be changed to 8 poles.

The captured mechanical power from the wind through pole control is very near to the theoretical maximum extracted power from the wind as depicted in Fig. 6.

The output electrical power from the generator is more or less follow the same manner as the input mechanical power (Fig. 7). The output electrical power is maximized when the number of poles is set to 4-poles for wind speeds higher than $9.2 \mathrm{~m} / \mathrm{s}$. Over the wind speed range from $9.2 \mathrm{~m} / \mathrm{s}$ and down to about $7 \mathrm{~m} / \mathrm{s}$, the generator output electrical power is the highest for 6-poles. At wind speeds lower than $7 \mathrm{~m} / \mathrm{s}$, that of the 8 -poles is the highest.

The stator and rotor currents (Fig. 8\& 9) decrease generally as wind speed decreases. An eye should be kept on these currents to ensure that they are within the permissible rated values. The investigation of these figures show that if the number of poles is changed corresponding to the specified wind speeds, the stator currents will be kept within the safe values (18.44 $\mathrm{A}$ for 4 poles, $14.98 \mathrm{~A}$ for 6 poles and $13.68 \mathrm{~A}$ for 8 poles).

The power factor curves (Fig. 10) indicate that changing the number of poles as the wind speed decreases below the middle wind speed value $(8 \mathrm{~m} / \mathrm{s})$ results in operation at better power factors. At low wind speeds, the power factor become negative as the generated power is low to the extent that it does not cover all the stator losses, and the machine draws electrical power from the supply to cover the rest of the losses.

\section{Conclusions}

Utilization of wind energy to generate electrical power is very vital. Cage induction generators- being cheap- can be used in small wind energy conversion system to replace the costly slip ring generators. To enhance the performance of such induction generator, pole amplitude modulation technique has been applied to increase the captured wind mechanical power, and hence the output electrical power.

Pole amplitude modulation method with three sets of poles has proved its effectiveness in this regard. At high wind speeds, the generator number of poles is set to the lowest number, and at medium wind speeds the number of poles is set to the medium value, 
while at the low wind speed the highest number of poles is used. Application of this control technique ensures the operation of the wind turbine around the maximum windenergy point at all wind speeds.

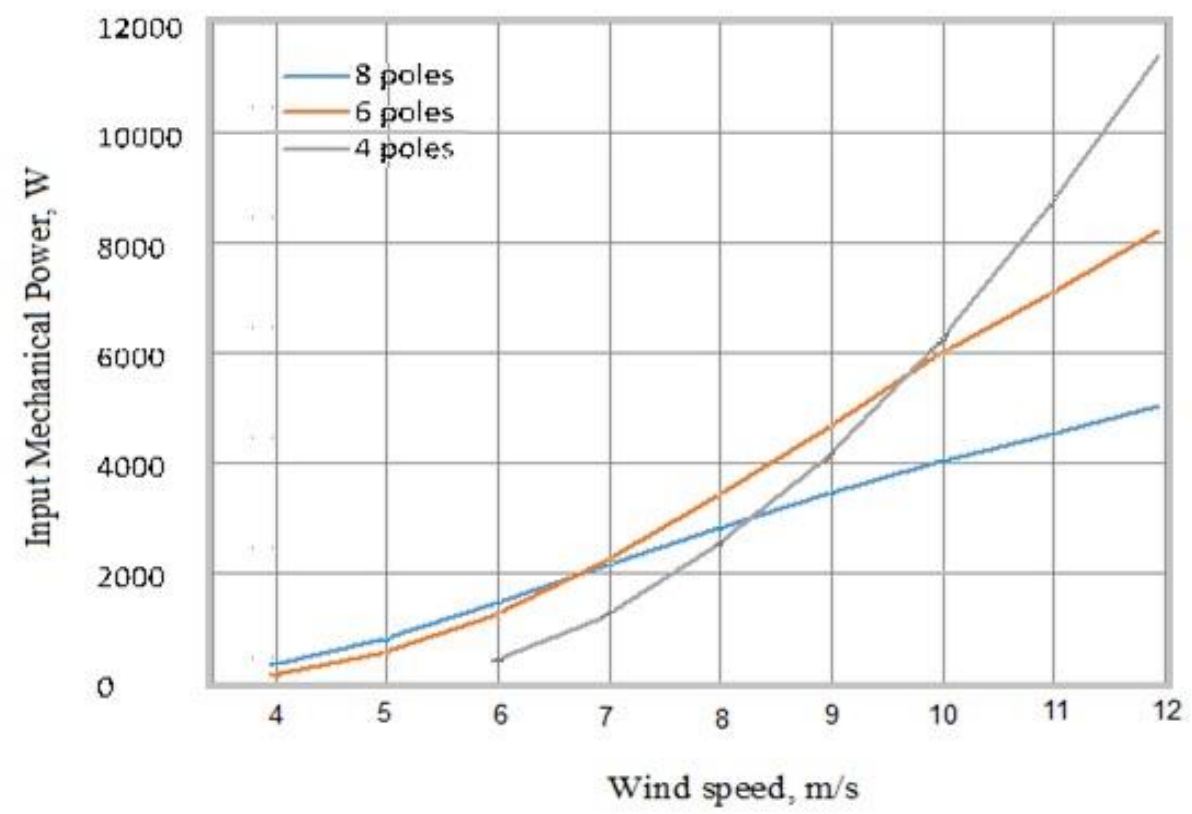

Fig. 5. Input mechanical power for the different number of poles versus wind speed.

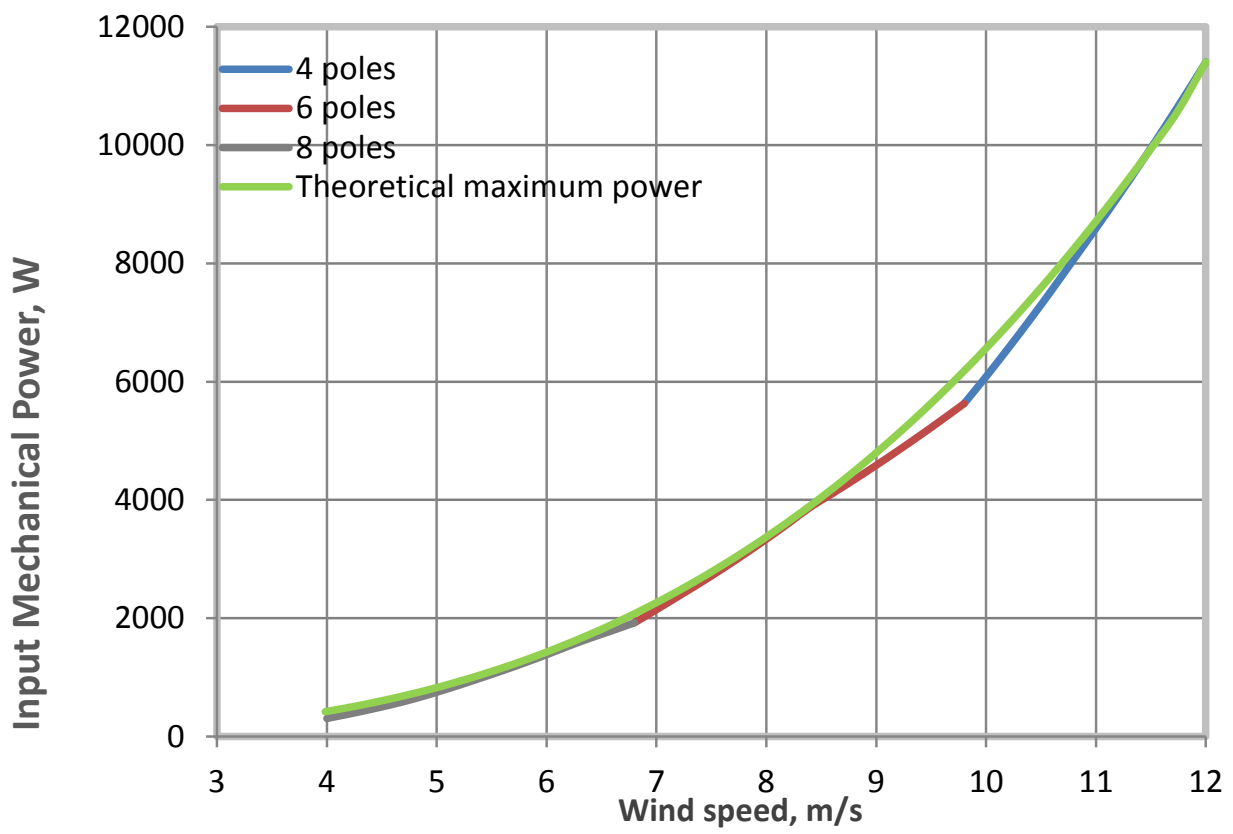

Fig. 6. Input mechanical power using pole control compared with the theoretical extracted maximum power. 


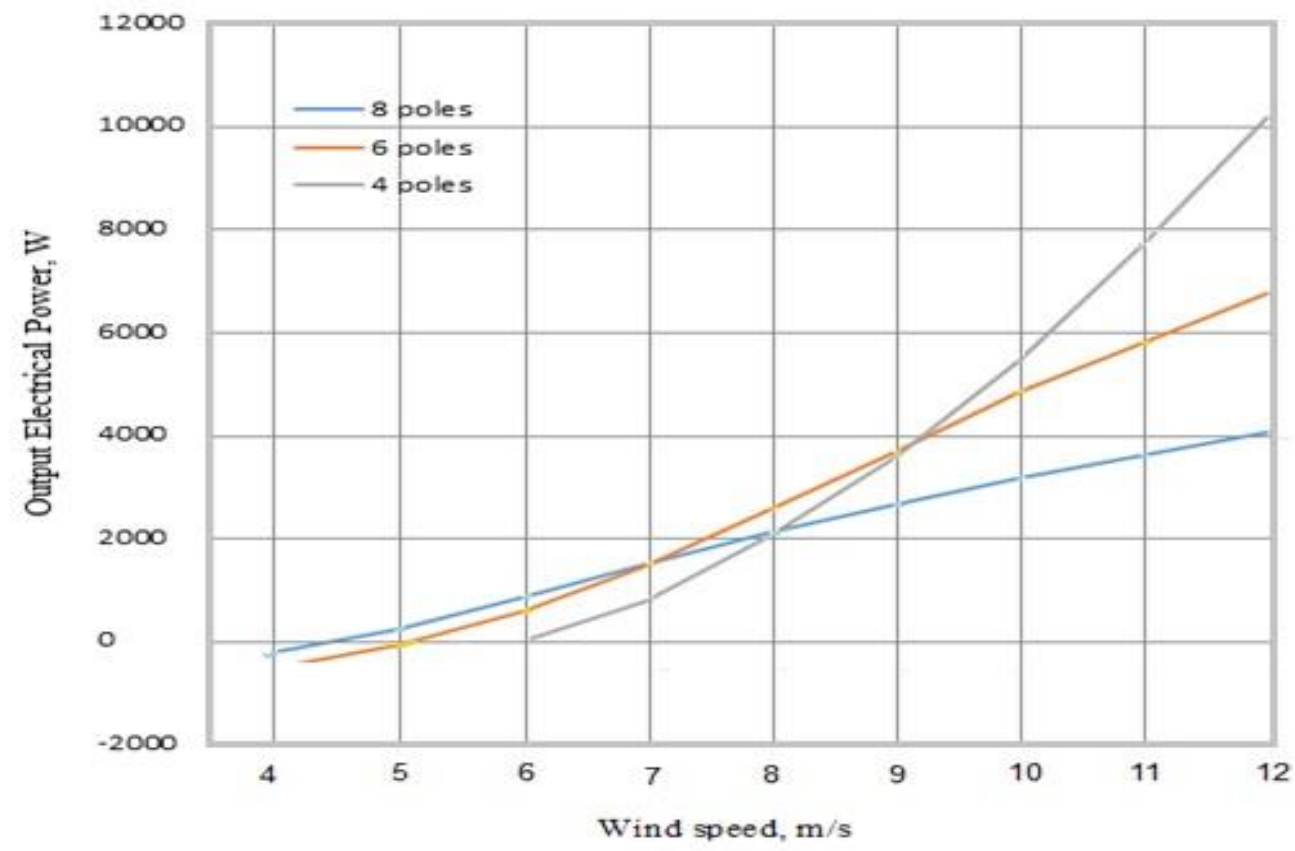

Fig. 7. Output electrical power for the different number of poles versus wind speed.

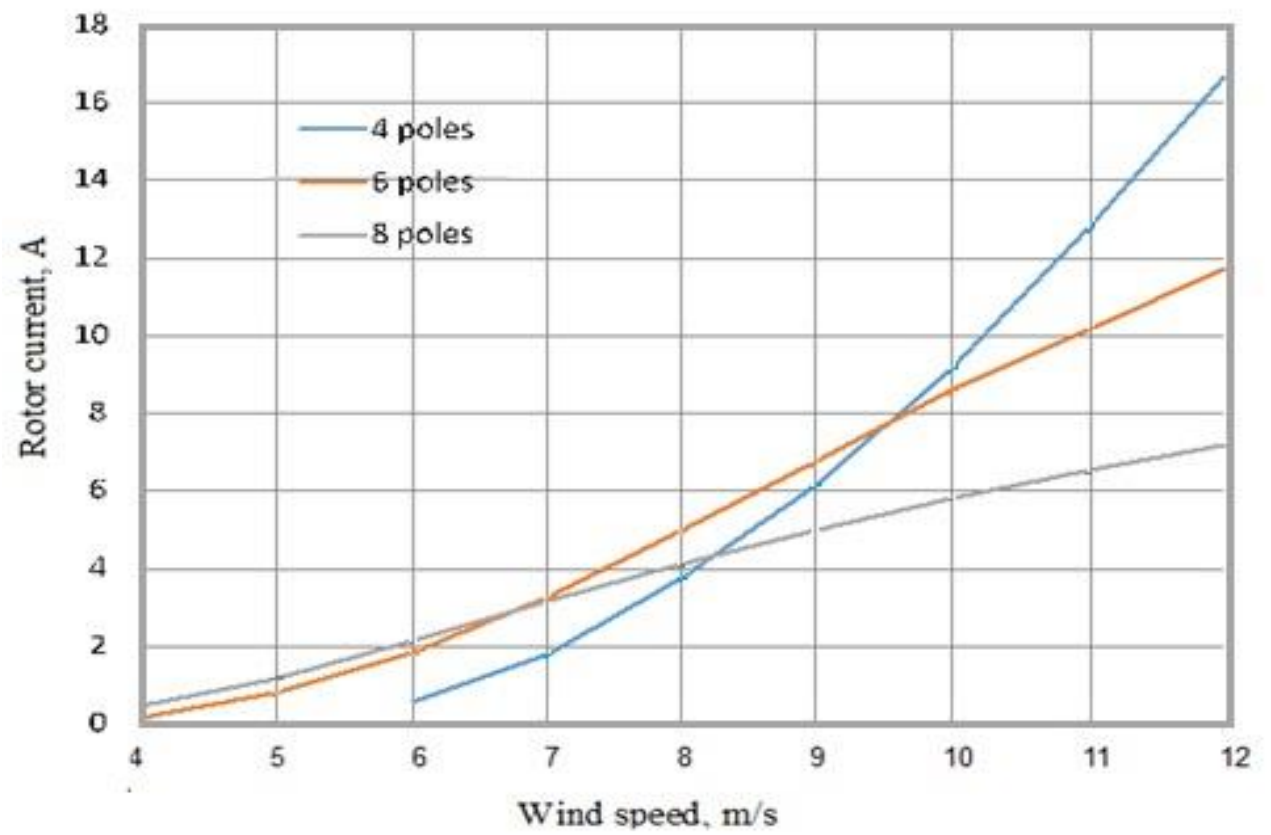

Fig. 8. The rotor current versus the wind speed at the different number of poles. 


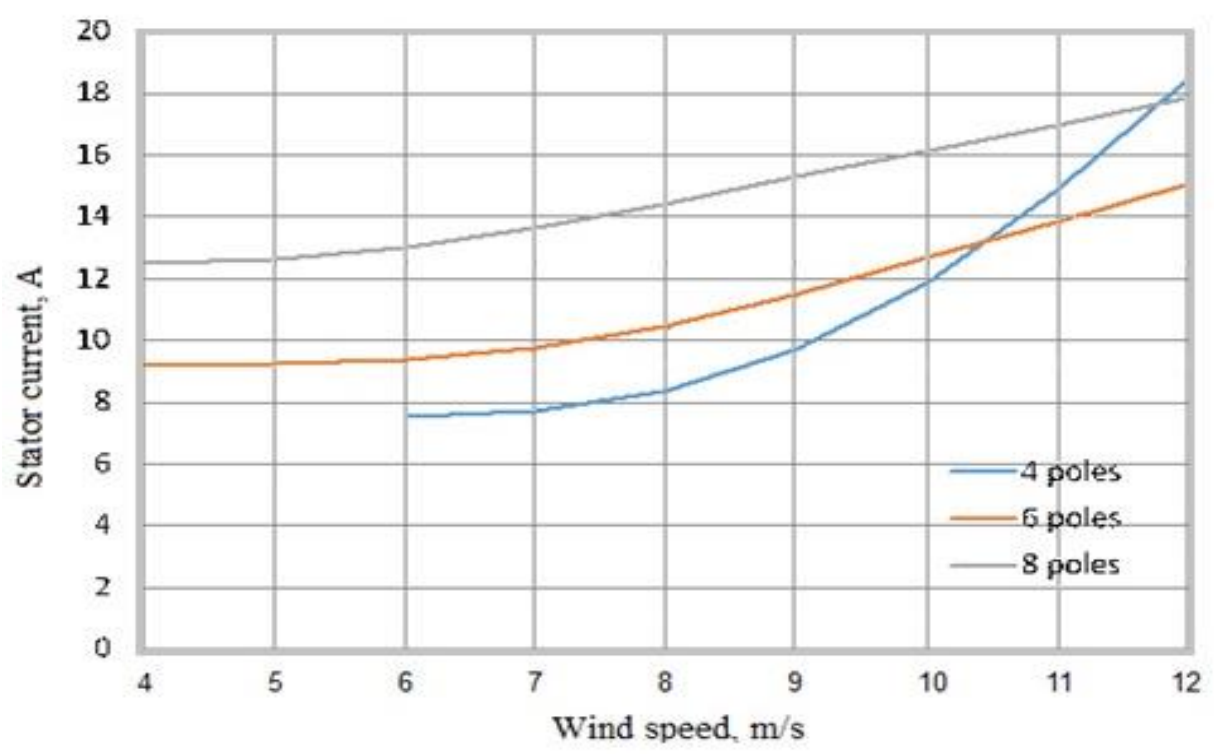

Fig. 9. The stator current versus the wind speed at the different number of poles.

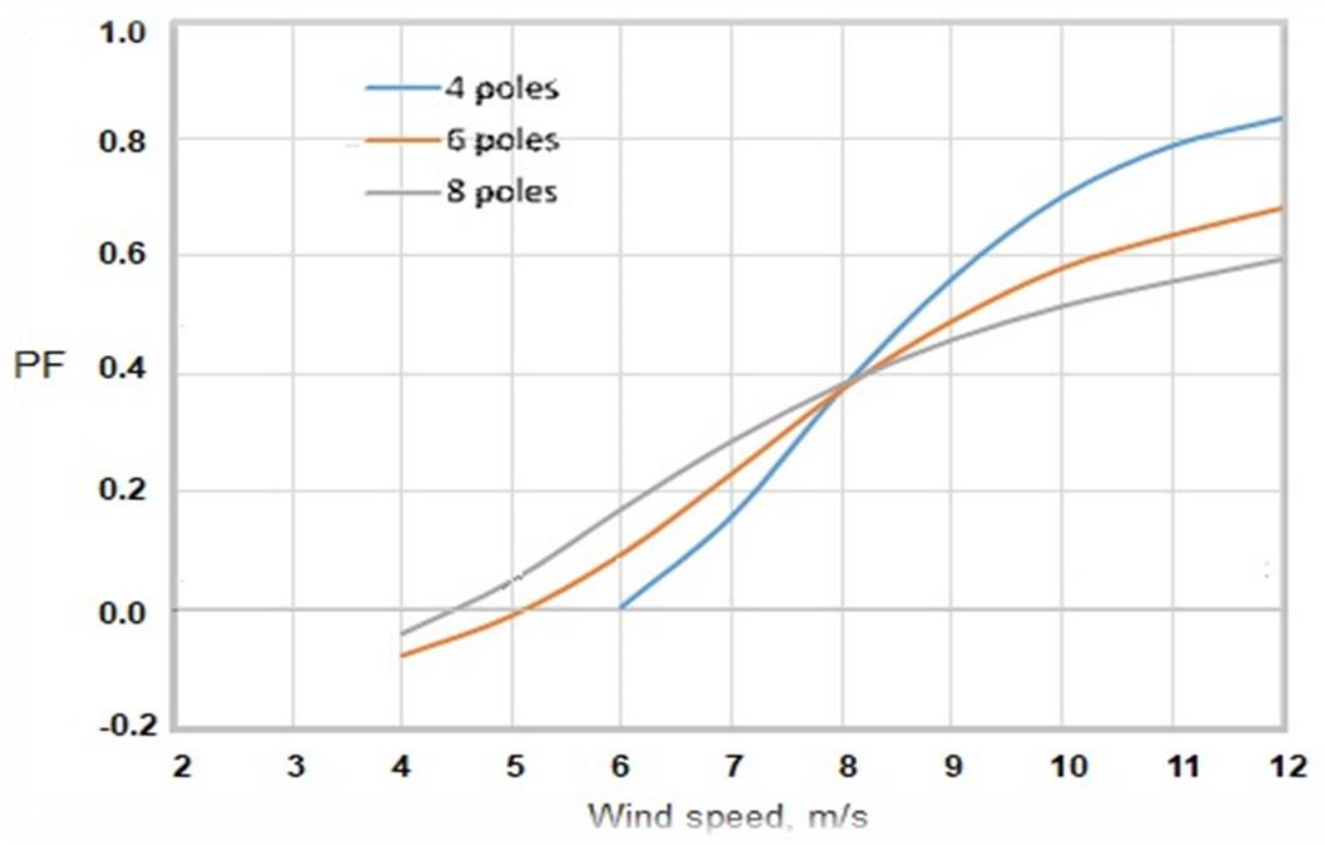

Fig. 10. Power factor versus the wind speed for different number of poles. 


\section{References}

[1] Singh, Bhim (1995) "Induction Generators-A prospective", Electrical Machines and Power Systems, 23: $163-177$.

[2] Subbiah, V. and Geetha, K. (1996) "Certain Investigations on a Grid Connected Induction Generator with Voltage Control", Proc. of the IEEE International Conference on Power Electronics, Drives and Energy Systems, New Delhi, India, Jan. 1996, pp: 439-444.

[3] Akhmatov, V. (2005) "Induction Generators for Wind Power", Multi-Science Publishing Co. Ltd., Essex, United Kingdom.

[4] Shaltout, A.A. and El-Ramahi, A. F. (1995) "Maximum power tracking for a wind driven induction generator connected to a utility network", Applied Energy, 52: 243-253.

[5] Abdel-halim, M. A., Mahfouz, A. A. and Almarshoud, A. F. (2014) "Enhancing the Performance of WindEnergy-Driven Double-Fed Induction Generators", Qassim University Scientific Journal-Engineering and Computer Sciences, 7 (1: 23-41.

[6] Boumassata, A., Kerdoun, D., Cherfia, N. and Bennecib, N. (2013) "Performance of Wind Energy Conversion Systems Using a Cycloconverter to Control A Doubly Fed Induction Generator", Energy Procedia, Available online at www.sciencedirect.com, 42: 143152.

[7] Abdel-halim, M. A. (2015), "Dual Control of Induction Generators for Tracing the Maximum Wind Energy", Journal of Engineering and Computer Sciences, Qassim University, 8(1) (January): 21-44.

[8] Abdel-Halim, M. A., Mahfouz, A. A. and Almarshoud, A. F. (2015) "Enhancing the Performance of a Stator and Rotor Combined-Controlled Wind-Driven Induction Generator", JKAU: Eng. Sci., 26(1), DOI: 10.4197/Eng. 26-1.1, pp: 3- 23.

[9] Boldea, Ion (2016) "Variable Speed Generators", 2nd Edition, CRC Press, Taylor \& Francis Group, Boca Roton,.
[10] Ruben, P. (2001) “A Cage Induction Generator Using Back to Back PWM Converters for Variable Speed Grid Connected Wind Energy System", Industrial Electronics Conference (IECON), 2: 1376-1381.

[11] Abad, Gonzalo, Lo'pez, Jesu's, Rodri'guez, Miguel A., Marroyo, Luis and Iwanski, Grzegorz (2011) "Doubly Fed Induction Machine-Modeling and Control for Wind Energy Generation," IEEE Press, Published by John Wiley \& Sons, Inc., Hoboken, New Jersey.

[12] Jian, Linni, Liang, Jianing, Shi1, Yujun and Xu, G. (2013) "A Novel Double-Winding Permanent Magnet Flux Modulated Machine for Stand-Alone Wind Power Generation", Progress In Electromagnetics Research, 142: $275-289$.

[13] Chandrasekar, L., Anbuchandran, S. and Sankar, R. (2015) "Performance Analysis of Pole Amplitude Modulated Three Phase Squirrel-Cage Induction Motor", International Journal of Emerging Technology in Computer Science \& Electronics (IJETCSE), 13 (March): 611-621.

[14] Bossanyi, E. (2000) "The design of closed loop controllers for wind turbines," Wind Energy, 3 (3): 149163

[15] Leithead, W. and Connor, B. (2000) "Control of variable speed wind turbines: Design task," International Journal of Control, 73 (13):1189-1212.

[16] Chapman, Stephen J. (2012), "Electric Machinery Fundamentals", 5th Edition, McGraw Hill-Higher Education, London.

[17] Shees, M. Munawar, Bakhsh, Farhad Ilahi, Ashar, M. S. Jamil and Abdel-halim, M. A. (2011), "Power Factor improvement of Combined Input Voltage and Slip Power Control of Low Power Wound Rotor Induction generator," International Journal of Engineering Research and Applications, 1(3): 962-968.

[18] Ackermann, T. and S*oder, L. (2002), "An overview of wind energy-status", Renewable and Sustainable Energy Reviews, 6 (1-2): 67-127. 


\section{Appendix 1: The Generator Data}

The studied cage generator is a 3-phase, 10/6.67/5 kW, $380 \mathrm{~V}, 50 \mathrm{~Hz}, 4 / 6 / 8$ pole amplitude modulated cage induction generator. The parameters of the generator are as follows:

\begin{tabular}{|l|l|l|l|}
\hline Parameters & 4 poles & 6 poles & 8 poles \\
\hline $\mathrm{R}_{1}, \Omega$ & 0.47 & 1.034 & 1.504 \\
\hline $\mathrm{R}_{2}, \Omega$ & 0.47 & 0.972 & 1.361 \\
\hline $\mathrm{X}_{1}, \Omega$ & 0.86 & 0.7568 & 0.86 \\
\hline $\mathrm{X}_{2, \Omega}$, & 0.7568 & 0.86 \\
\hline $\mathrm{X}_{\mathrm{m}}, \Omega$ & 0.86 & 23.129 & 29.55 \\
\hline $\mathrm{R}_{\mathrm{c}}, \Omega$ & 28.27 & 409.07 & 522.710 \\
\hline $\mathrm{R}_{\mathrm{T}, \Omega}$ & 500 & 0.968 & 1.412 \\
\hline $\mathrm{X}_{\mathrm{T}}, \Omega$ & 0.444 & 0.77 & 0.899 \\
\hline Stator Rated Current, A & 0.8396 & 14.98 & 13.68 \\
\hline Stator Connection & 18.44 & Star & Delta \\
\hline
\end{tabular}




\section{تعظيم القدرة الخارجة من مولد حث مرتبط بالثبكة ومدار بطاقة الرياح من خلال التحكم في الأقطاب}

محمد عبد السميع عبد الحليم، و عبد الكريم عبد المحسن الغتيم

كلبة الهندسة، جامعة القصيم، أمانة منطقة الفصيم، القصيم، المدلكة العربية السعودية

masamie@qec.edu.sa

الدستخلص. في هذا البحث تم ربط مولد حثي قفصي بالثبكة الكهربائية، وتم إدارته بطاقة

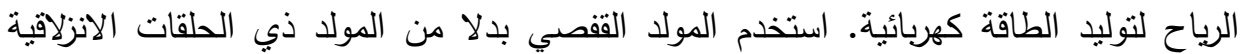
غالي الثن. ونم تحسين أداء المولد القفصي بأسلوب منخفض التكاليف، وهو التحكم في عدد التحد أقطابه لكي يتوافق مع سرعة الرياح، بحيث نعظم الطاقة الميكانيكية المستخرجة من الريح. وفي

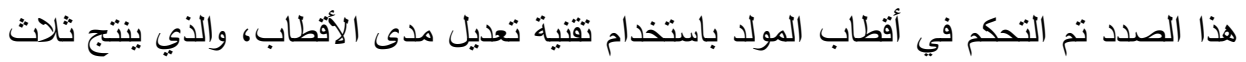
مجموعات من عدد الأقطاب. أثثتت الننائج إمكانية تطبيق هذه الطريق وفاعلية تأثيرها في زيادة

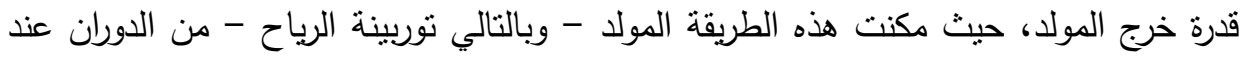
سرعات تساوي أو قريبة جدًا من السرعات المثالية، والتي عندها تسنخرج أعلى طاقة رياح. كلمات مفتاحية: طاقة الرياح، مولد حثي مربوط بالثبكة، تعديل مدى الأقطاب، مولد حثي ققصي. 
